\section{Behaviour genetics}

The Genetics of Behavior. By Lee Ehrman and Peter A. Parsons. Pp. viii +390 . (Sinauer Associates: Sunderland, Massachusetts; Freeman: Reading, June 1976.) $£ 11.50$.

BEHAVIOUR genetics is not easily organised into textbook form, as it's literature covers a very diverse range of topics in a patchy fashion. Ehrman and Parsons have chosen to group their material according to experimental approach and experimental animal. There are chapters on 'single genes and behaviour', 'many genes and behaviour', 'Drosophila', 'Rodents', 'other creatures', 'man-continuous traits', 'man - certain discontinuous traits', and so on. Their decision is reasonable but it presents them with problems, for such groupings are not the best for bringing out the main questions to which behaviour genetics should be applied. This book was written just too early to have taken account of the sociobiology upsurge. Here, for example, we have an infinity of attractive theories confidently proposing a genetic basis for a huge range of complex social behaviour. Yet we know next to nothing about the way the simplest behavioural potential is encoded in genetic terms. This main question quickly breaks down into a cluster of questions concerning genes and behavioural development, and gene environment interactions. Of course, these and other major questions do emerge from Ehrman and Parson's book, but I think they should have been more strongly accented, to give some structure to their review of the very disparate literature, only a few of whose studies really lead somewhere.

This will, however, be a most useful textbook; it is certainly the best since Fuller and Thompson produced the first complete survey of behaviour genetics in 1960. Ehrman and Parsons write very well, their style is generally light and attractive. They begin with a chapter of essential genetics and I would judge that even students with no biological background could then go on with little trouble. The examples they cite are described thoroughly, with good illustrations and tables. Although I might quibble with the balance in places, they have certainly drawn together a scattered literature with great skill. Both authors are primarily geneticists and at times, I find the behavioural component lacking in depth. For example, their accounts of Dilger's work on hybrid parrots and Sharpe and Johnsgard's duck hybrids miss some of the points.

The chapters on human behaviour genetics are very good. The real test here is the treatment of the genetics of intelligence issue and this is the best modern account I know, steering a very clear and reasonable course, missing none of the genetical or social issues.

Fhrman and Parsons end with a chapter on the evolutionary implications of behavioural changes, and then finally give their appraisal of future directions for behaviour genetics. I don't really share their conviction that it will emerge as a distinct discipline, but genetics will remain a vital technique in tackling some of the most fundamental behavioural problems. This textbook can be warmly recommended to teachers and students alike.

Aubrey Manning

Aubrey Manning is Professor of Natural History at the University of Edinburgh, $U K$.

\section{Ice on the \\ land}

Glaciers and Landscape: A Geomorphological Approach. By David E Sugden and Brian S. John. Pp. viiit 376. (Edward Arnold: London, April 1976.) Boards £12; paper $£ 5.95$.

GLACIOLOGY and geomorphology are typical of many scientific subjects the early disciples of which, with a minimum of equipment, made bold observations from patient work almost always pursued in isolation. Since 1950 the pattern has changed to team work, sophisticated equipment, the sharing of investigation areas and special publications. Devotees from all industrialised nations meet regularly to learn of progress and methods, and to swap yarns of experience, always told with humour and understatement by those who, particularly in these two disciplines, raise their eyes to the hills from 'whence cometh their health'. Laboratory work has provided specific laws but the wide range of variables in natural processes in the field always raises new problems in the application of these laws to the observed landscape.

Glaciology is advanced primarily by physicists whereas geomorphology is lead by physical geographers. The authors are reputable glacial geomorphologists who appeal for investigations to link these two aspects more closely. The book systematically sets out a brief for the geomorphologist to recognise the scope of the ice problem and summarises what the glaciologist has done to assist.

There are five parts, each of three chapters. The first part, 'Glaciers and Glacier Dynamics', gives the basic properties of ice, the environmental factors influencing it, the morphology of glaciers both en masse and in surface structure. Fundamental quantitative relations are limited to this first part.

"Glacier Distribution in Space and Time' provides a succinct summary of the ice on the Earth's surface and its fuctuations. The authors rightly criticise the overdramatisation by the media of the relation between glaciers and climate and conclude that reliable assessment of this relationship can only be made for high frequency events of low magnitude since precise data is only available for minor oscillations over the past few decades. The random element in oscillatory behaviour becomes more marked as the time scale increases.

The next two parts, 'Glacier Erosion' and 'Deposition', each give a chapter on process followed by ones on landforms and landscapes. Rock abrasion, meltwater transport and deposition of rock detritus, the characteristics of tills and the complex end-products of both processes are economically described. Meltwater phenomena extend well beyond the margins of present ice but the authors sensibly limit their account to the present glacierised phase.

The final part, 'Meltwater, a glacial subsystem', discusses a component in all glaciers that in recent years has received much attention from glaciologists and engineers. It is a very creditable account of an aspect that most authors have combined with erosion and deposition. As in the first part of the book, there is already new material to be incorporated, a common difficulty for authors in a subject developing so rapidly.

Each chapter ends with suggested 'Further Reading' and there is an index at the end of the book, preceded by 25 pages of references, since the authors have patiently sifted an extensive range of literary and photographic material, very well drafted and printed in the book. Almost every page has a diagram, a photograph, a table, a schematic model; and although the models are entirely qualitative and the authors admit that some will rapidly be superceded, most are new and will be welcomed by students being increasingly taught classifying systems.

Few books are better presented for the price and none more captivating to the reader interested in the fascinating phenomenon of ice on the land.

H. Lister is Reader in Physical Geography at the University of Newcastle upon Tyne, a member of the International Glaciological Society and of the British Geomorphological Research Group, and escapes to mountains and glaciers whenever possible.

H. Lister

Dr Lister is a Lecturer in the Department of Geography at the University of Newcastle-upon-Tyne, UK. 